\title{
FROM STUDIES TO THEMATIC ISSUES - SYMPTOMS OF TRANSITION/MOBILITY OF THE INTERNATIONAL MAGAZINE FOR MUSIC NEW SOUND
}

\author{
Vesna Mikić* \\ University of Arts in Belgrade \\ Faculty of Music \\ Department of Musicology
}

\begin{abstract}
The paper presents one possible interpretation of the position, meaning and form of the Studies section as one of the 'pillars' of the International Magazine for Music New Sound. The interpretation includes statistical and historical data, as well as theoretical viewpoints used in considerations of the process of transition. Using the Studies section as a case study, two periods in the activity of New Sound have been recognized, and these periods can be brought into relation both with the periods of transition in Serbian society and with the global transition processes which leave their imprint on our professional and social activities.
\end{abstract}

Keywords: Novi Zvuk, New Sound, the Studies section, studies, thematic issue, transition

Апстракт: Текст је посвећен једној од могућих интерпретација позиције, значења и форме рубрике Студије као једне од носећих рубрика Интернационалног часописа за музику Нови Звук. У интерпретацију су укључени статистички, али и историјски подаци, те теоријске позиције које се користе у разматрањима процеса транзиције. Уочена су, на примеру Студија, два периода делатности Новог Звука, а ти се периоди могу довести у везу с периодима транзиције у српском друштву, али и са глобалним

\footnotetext{
* Author contact information: mikic@eunet.rs

The paper was written within the project Identiteti srpske muzike u svetskom kulturnom kontekstu [Identities of Serbian Music in the World Cultural Context] by the Department of Musicology of the Faculty of Music in Belgrade, supported by the Ministry of Education, Science and Technological Development of the Republic of Serbia, under Reg, No. 177019
} 
транзицијским процесима који се уписују у наше професионалне и друштвене активности.

Кључне речи: Нови Звук, рубрика Студије, студије, тематски број, транзиција

'Mislim da je u primeru Zvuka moguće reći da su diferencijacije koje su se pojavile od vremena do vremena, uprkos osciliranju kvaliteta, dosada, uopšte uzev, odjeknule pozitivno. Ponekad su prouzrokovale relativno dizanje nivoa, a gotovo uvek težnju za postupnim usavršavanjem... Zvuk (ima) ne samo aktualni, nego, u određenom smislu, i istorijski značaj. Bez obzira na različita mišljenja i gledišta koja su bila izrečena protiv njega ili njemu u korist tokom njegovog dosadašnjeg izlaženja, moguće je njegove rezultate označiti kao pozitivne. Cilj koji mu je nekada postavio njegov utemeljivač bio je uglavnom dostignut.'

The evaluation expressed by Dragotin Cvetko on the occasion of the hundredth issue of the magazine Zvuk, which belongs naturally to the discursive framework of the context and time in which it was written, apart from the obvious 'resonance' with the writer's task at hand - speaking of the magazine and/or its sections on the occasion of its jubilee - resonates also with actual questions related with the International Magazine for Music New Sound, regarding the continuous existence of conflicting opinions on 'its publication', as well as the need to respect, follow and nurture the set goal of its 'founder'. ${ }^{2}$

Therefore, in spite of all the possible differences in the discursive framework/context in which we observe New Sound today - but which also existed, to some extent, in the time when it was launched - the basic premise of its founder, as well as the expectations, needs and positions of its key sponsors

\footnotetext{
1 'I think that, regarding Zvuk, one can say that the differentiations, which appeared from time to time, in spite of fluctuations in quality, have met so far with a generally positive reception. Sometimes they caused a relative increase in level, and almost always an ambition for progressive improvement... Zvuk does not (have) only topical, but also, in a certain sense, historical significance. In spite of various opinions and views expressed against it or in its favour during its publication so far, its results can be qualified as positive. The goal once set by its founder has been reached for the most part.' Dragotin Cvetko, Uz stoti broj Zvuka [With the Hundredth Issue of Zvuk], Zvuk, 1969, 100, 475, quoted after: Roksanda Pejović, Četiri jugoslovenska Zvuka [Four Editions of the Yugoslav Magazine Zvuk (Sound)], Internacionalni časopis za muziku Novi Zvuk, 1, 1993, 29-54.

2 'Novi Zvuk se pokreće kao internacionalni časopis za muziku, čiji je cilj propagiranje domaćeg muzičkog stvaralaštva i teorijske misli o muzici - muzikološke, etnomuzikološke, analitičke, filosofske, estetičke...' ['New Sound is being launched as an international magazine for music, whose goal is to promote domestic musical creation and theoretical thought on music - musicological, ethnomusicological, analytical, philosophical, aesthetic...'], Mirjana Veselinović-Hofman, 'Reč urednika' ['Editor's Word'], Internacionalni časopis za muziku Novi Zvuk, 1, 1993, 5.
} 
have not significantly changed. One could say that the first twenty years of New Sound passed in the 'struggle' for a different perspective on the ways of promoting contemporary (domestic) music - a belief conceived consciously, promoted through the activities of New Sound Editorial Board and expressed through fighting for the (creative) autonomy of all types of (inter)disciplinary practices in speaking about music. At the same time, this period was marked by particular 'battles' within the disciplines, which in various ways deal not only with music, but also with global and local socio-economic changes of 'high voltage'. Thus, for example, the accents and reverberations of the (international/ Anglo-Saxon) 'conflict' between the 'old' and the 'new' musicology, or the general shift of focus from aesthetic to theoretical issues in history/philosophy/the theory of arts, have been imprinted in the papers of New Sound, just like market forces, technological breakthroughs and institutional standards have, by their nature, been reflected in the aspects of the magazine's technical standards and, occasionally, in its thematic decisions and manners of their interpretation.

One could say that if there is a section in New Sound which might stand out as the persuasive agent of the program/position of a 'new sounding' of theoretical thought on music, it is certainly the Studies section. Since something can be 'new' only in relation to something 'old', it must be mentioned that the 'harbingers' of the section did exist in the Sarajevo edition of Zvuk (occasional section Studije i eseji [Studies and Essays]), ${ }^{3}$ as well as in the Zagreb edition. Nevertheless, the advancement from an occasional to a 'supporting' section shows that the said struggle for autonomy has become an 'independent' one and that various kinds of theoretical discussion have been opened about music. Also, the formal 'position' of the section - right after the Composer Speaks section - speaks of the significance attached by the Editorial Board to this kind of contribution.

In the forty issues of New Sound, the section was excluded only in two instances. However, this still does not mean that the exploratory-interpretative dimension of the study contributions was 'avoided' in these cases. Thus, on the occasion of Josip Slavenski's anniversary, the 'position' of studies in Issue $7,{ }^{4}$ under the title Anniversaries, was taken by Mirjana Živković's study 'Težnja ka višem umetničkom redu' ['Striving for a Higher Artistic Order'] (pp. 15-22) and Pavle Stefanović's essay 'Drama umetničkog stvaralaštva Josipa Slavenskog' ['The Drama of Josip Slavenski's Artistic Work'] (pp. 23-28). Also, in Issue 14 (II/1999), ${ }^{5}$ Studies were replaced by New Sound's Thematic Series,

3 Cf. Roksanda Pejović, Četiri jugoslovenska Zvuka, op. cit.

4 The list of all the studies by issues can be found in the Appendix.

5 Possibly such a situation was caused by the fact that it was the autumn issue in 1999 , when the NATO bombing took place (at the end of March), and according to the order estab- 
introduced in the preceding issues and containing Pierre Albert Castanet's contribution 'Une approche française de la musique micro-tonale' (pp. 23-29). A recurring subject in Issues 9 to 18 (1997-2001), the theme Music on the Eve of the Third Millennium demonstrated in a unique manner the research of various ways of rendering thematic magazine issues. Hence, although it was a part of New Sound's Thematic Series instead of Studies, we shall nevertheless mention this section, which was, understandably, cancelled at the beginning of the new millennium. It is no surprise that the papers in this section were written mostly by foreign authors ${ }^{6}$ since the main idea were deliberations about the current state of affairs on various musical scenes, as indicated in the 'introductory' text 'Srpska muzika i "zamrznuta istorija” (Uz pokretanje tematske serije Muzika uoči trećeg milenijuma)' ['Serbian Music and "Frozen" History (Initiating the Thematic Series Music on the Eve of the Third Millennium)'] by New Sound's editor Mirjana Veselinović-Hofman, PhD.

These two 'situations' can be regarded as 'symptoms' of the future positioning and orientation of both the section and New Sound. Because, in time, the anniversaries, reminiscences, and various problem circles will grow into the practice of publishing thematic issues, at first carried out discreetly in Issue 23, through the 'extension' of the Composer Speaks section by the reminis-

lished at that time, contributions for the year's autumn issue were collected in the first trimester (the deadline being on the $30^{\text {th }}$ April).

6 Ulrih Dibelijus [Ulrich Dibelius], Komponovanje uprkos dogmatskom pritisku [Komponieren gegen den Dogmenzwang], Internacionalni časopis za muziku Novi Zvuk, 10, 1997, 17-28; Tatjana Petrović, Komunikacija kao imperativ stvaranja [Communication as an Imperative of Creation], ibid., 29-32; Linas Paulauskis, Savremena litvanska muzika: pokušaj sagledavanja [Modern Lithuanian Music: An Attempted Survey], Internacionalni časopis za muziku Novi Zvuk, 11, 1998, 13-22; Arnold Berlijan [Arnold Berleant], Neka zapažanja o današnjoj američkoj muzici [Some Thoughts on Contemporary American Music], Internacionalni časopis za muziku Novi Zvuk, 12, 1998, 21-24; Marija-Tereza Lefevr [MarieThérèse Lefebvre], Doprinos žena istoriji muzike u Kvebeku [La contribution des femmes à l'histoire de la musique au Quebec], ibid., 25-31; Tatjana Petrović, Komunikacija kao imperativ stvaranja [Communication as the Imperative of Creation], ibid., 33-35; Ole Henrik Moe, Strani tonovi - novi podstrek, Internacionalni časopis za muziku Novi Zvuk, 13, 1999, 23-27; Marsel Kobasen [Marcel Cobussen], Uloga ansambala u muzičkom životu Holandije: Heterogenost, angažman i društvena utemeljenost [The Dutch Ensemble Culture: Its Heterogeneity, Commitment and Social Embeddedness], Internacionalni časopis za muziku Novi Zvuk, 15, 2000, 33-44; Eduardo Miranda, Kompozitori i tehnologija kompjuterske muzike u Brazilu [Composers and Computer Music Technology in Brazil], Internacionalni časopis za muziku Novi Zvuk, 17, 2001, 13-26; Svetlana Savenko [Светлана Савенко], Avangarda i sovjetska muzika [Авангарда и советская музыка], Internacionalni časopis za muziku Novi Zvuk, 18, 2001, 21-27. The surveys arranged by Tatjana Petrović were conducted in conversations with foreign composers. 
cence about 'tablets' and texts by Ljubica Marić. It is intriguing that the forerunners of the thematic issues were dedicated to music practices which are, obviously, considered in most cases to be located 'outside' the standard musicological discourses - to popular music (Issue 13, I/1999) and World Music (Issue $24, \mathrm{II} / 2004)$ - while it is certainly indicative that the 'conquest' of thematization still relied on the previously adopted formal disposition expressed by the (not always possible/attainable) formula: at least two studies per issue. Thus, popular music, World Music, as well as acousmatics (Issue 26, II/2005), which are symptomatic cases, adhered to the same pattern: Issue 13 contained three studies (Krstić, Janjatović, Levi), Issue 24, two of them (Veselinović-Hofman, Šuvaković), and Issue 26 included two studies on the phenomenon of acousmatics (Hamilton, Šiler [Schüler]), while the remaining two followed New Sound's specific (and already noted) repurposing of 'anniversaries' (Roksanda Pejović, Dejan Despić) into Studies (Marković, Stefanović).

The second trajectory leading to the concept of thematic issues in which reliance would be placed on the Studies section was traced in Poststrukturalistička nauka o muzici [Poststructuralist Science of Music], a special issue of New Sound on the occasion of 50 years of the activity of the Belgrade Faculty of Music's Department for Musicology (the papers were publicly presented at a departmental conference held in June 1998), as well as in Issue 16 (II/2000), containing the research submitted at the scientific meeting 'Duhovna muzika balkanskog regiona' ['Spiritual Music of the Balkan Region'], held in Belgrade on the occasion of 2000 years of Christianity. The special edition, understandably, was oriented towards the promotion of research results and the proclamation of the theoretical positions (blasphemously modern at the time) of domestic musicologists and ethnomusicologists professionally associated with the Faculty of Music, while Issue 16 justified both the international - by publishing the contributions of German, Macedonian, Greek and Romanian colleagues - and the interdisciplinary dimension of the magazine.

The already appreciable movement/transition towards the transparent/obligatory thematization of every autumn issue, described in the case of the issues between 20 and 30, was crowned by a fusion of the 'old' and the 'new' - of a 'jubilee' issue and a thematic issue (or a virtual symposium) in Issue 28 (II/2006). Transitional Mokranjac, or the transition of Mokranjac that took place in 2006, on the $150^{\text {th }}$ anniversary of the composer's birth, ${ }^{7}$ was marked in the case of New Sound by the context of the 'politically correct' terminology of the European

7 For more details cf. Vesna Mikić, 'Naš' Mokranjac - Tranzicijske kulturne prakse i delo Stevana Mokranjca ['Our' Mokranjac - Transitional Cultural Practices and the Work of Stevan Mokranjac], Mokranjac, časopis za kulturu, Issue 14, December 2012, 2-12. 
Union, but also that of new musicological discourses, in the contributions which dealt with the subject 'Choral Production of Southeastern Europe - to Stevan Mokranjac'. Thus, for the first time, a theme and an impressive number of studies were joined together, foreshadowing the transition of the Studies section into the Core Issue, which would take place once every following year.

Although - if, for a short moment and in one general glance, we pay attention to the 'standard' contributions within the section in order to avoid the valuational overtones which might have 'appeared' in the previously presented analogy, we will note that the editorial policy was guided by two obvious strategies. Exceptional care was taken to have contributions from musicology and ethnomusicology as two 'sister' disciplines (although one could use other familial metaphors in this particular case) equally represented, while foreign papers were published whenever that was possible. In that regard, the Studies section assumed the role of 'guardian of the fire', because it is this section which is expected to maintain the continuity of disciplinary endeavours, as well as the international component of the magazine. Paradoxically, studies are (traditionally) expected to achieve breakthroughs into the 'new', and so, in that respect, this section of New Sound turns out to be the exact place where diverse creative vivacities of theoretical thought on music and arts are to be presented. Regarding the former of the two strategies, it should be said that it was directly dependent on institutional guidelines and the history of musicological science in our midst. Thus, the magazine's Editorial Board, since the very beginning, has included the doyen of Serbian ethnomusicology, Dragoslav Dević, PhD. Bearing in mind the short, though every bit as exciting history of the magazine, but also that of our institutions, it appears that the 'break-up' which, in the institutional sense, occurred between musicology and ethnomusicology (if only in the case of the Belgrade Faculty of Music, which was soon followed by the transfer of the magazine to the Department of Musicology), led to adhering less 'strictly' to the strategy of 'level'/parallel presentation of musicological and ethnomusicological contributions in the magazine. Namely, the early issues of the magazine obviously adhered to the recommended policy of presenting both musicological and ethnomusicological items 'equally' and 'mandatorily', and there were moments (apart from the described 'trespasses' in the Issues 7, 13, 14), when only musicological or only ethnomusicological contributions were published. In the light of the fact that the number of scientifically active ethnomusicologists, both in the time of the magazine's launching and for the better part of its history, has been relatively small compared to the number of musicologists, there certainly were objective reasons for the lesser share of ethnomusicological items. Therefore, although about a quarter of the texts in the Studies section were written by ethnomusicologists, one should not lose sight of the circumstances in 
which musicology and ethnomusicology developed in Serbia, as well as the fact that ethnomusicological papers were published in other sections of New Sound. Also, this insight makes it possible to consider some situations which, over the course of time, have evolved at the broader institutional and social level, and which can help us to, if not understand, then at least perceive the complexity of the form, position, appearance and achievements of the Studies section in the last 40 issues, i.e. 20 years. However, before we address this consideration, we shall briefly summarize the latter of the two mentioned strategies - 'internationalism'. Similar to the former one, the results of this strategy's screening will attest to the complex network of social-economic-technological/biopolitical mechanisms in which the practices of the magazine publishing, the practices of the conceptualizations of its themes and sections, the practices of generating the objects of its analysis, of its disciplines - practices of writing (the contributions for the magazine) take place. The magazine's international orientation was made official by its international Editorial Board, and confirmed in the utmost measure by the papers which can be classified as studies. Slightly less than a half of the contributions in the Studies section (about sixty) were written by foreign authors engaged in various theoretical disciplines (musicology, ethnomusicology, aesthetics, performance studies, media studies, theories of arts and media...) and from various continents and parts of the world. But what is particularly intriguing - and this takes us back to the problems which might be united by the discoveries related to both of the strategies involved - is the fact that the foreign items, i.e. the thematic issues of New Sound, have become much more frequent in recent years. On the one hand, it is undisputable - now we are returning to the issue of the 'sponsor' - that the standards which the state institutions responsible for scientific magazines use for establishing their own categorizations, and which are vitally important for these publications, are such that encourage (or rather: force) the editorial boards to include a certain mandatory share of international items, a circumstance which evidently benefits New Sound, though it does require exceptional efforts on the part of the Editorial Board. Hence, the non-thematic, 'free', spring issues of New Sound have recently presented to the readership a significant number of studies (and contributions in other sections) by foreign scientists. ${ }^{8}$ On the other hand, the standards thereby favoured publications in the English language only. From the very beginning, the bilingual New Sound was, luckily, ready for these challenges of Serbian transition, and hence

8 For example, Alexandros Charkiolakis, The War Requiems by Benjamin Britten and Dmitry Kabalevsky: A Story of Differences, International Magazine for Music New Sound, I/2011, 15-23; Bogumila Mika, Novelty in the Polish Music Avant-Garde Discussion in the Late 1960s and Early 1970s, ibid., 35-46. 
the last ten or so issues have been printed in English only. Finally, it has already been mentioned that the first online issue of the magazine was uploaded on the Internet in 2004 (Issue 24) and ever since, all the subsequent English-language issues are available on the Web. In that respect, the international magazine acquired its global dimension, and the 'invigoration' of its international element can be interpreted from this technological aspect.

Additional factors which may help us understand the 'fate' of the scientific studies in New Sound are certainly concerning the fact that recent years have seen the succession of generations which, encouraged by institutional changes (this time in the educational system), have resulted in the most diverse openings and interlocking of disciplines that deal with speaking about music. This trend is clearly shown by the subjects treated in the thematic issues - ballad (Issue 30), improvisation (Issue 32), futurism (Issue 34), music and stage (Issue 36) and contemporary music at the fringe (Issue 38) - and the interdisciplinary variety of the approaches. Thus, the transition of the Studies section must be interpreted along these lines. Because this concise summary of twenty years, forty issues and about one hundred and fifty papers, along with "brief contacts" with those synchronous points of the institutional, social and technological history of the context in which they have appeared, also denotes a possible 'periodization' in the section's content.

During the first period of the Studies section - or roughly, the first decade of activity (up to 2004 and the first thematic and online issues ${ }^{9}$ ) - we can follow the movement from 'free' studies to studies that comply with the core issue, while the second period (the second decade, from Issue 25) is formally marked by the expansion from studies to thematic issues, and the even-numbered issues 'abandon' the section title: the studies underwent a transition into the core issue. It is as if the changed circumstances of the market (other musicological/ethnomusicological magazines have also been launched in Serbia in the meantime, and New Sound's financing has become 'unstable'), of institutions (the regulations of the state agencies have been altered, and the magazine is now under the authority of the Department of Musicology of the Faculty of Music) and of technology (all the possible aspects of living in a techno-culture), as well as those related to practices in the production, distribution and reception of music, have joined together to confirm (in the Studies section, but not only there) the validity of the vision of the 'founder' of the International Magazine for Music New Sound.

Translated by Goran Kapetanović

9 Since 2009 with a new design (Saša Ćurčić), at the address http://www.newsound.org.rs 


\section{Appendix}

\section{International Magazine for Music New Sound, STUDIES}

\section{No. 1, I/1993}

Roksanda Pejović, Four Editions of the Yugoslav Magazine Zvuk (Sound)

Dimitrije O. Golemović, When the Instrument Speaks Up

David Baron, Creation and Technology in a New World

Jasminka Dokmanović, The Ritual Singing of Women in the Shopluk Regions in Serbia

Nadia Mankowskaya, L’Esthétique musicale et le postmodernisme

\section{No. 2, II/1993}

Sonja Marinković, Vojislav Vučković and New Realism

Ana Kotevska, The Principle of Hierarchy (Seniority) of Traditional Musical Values as a Way to Maintain Cultural Identity in Western Africa

\section{No. 3, I/1994}

Mladen Marković, Ethnomusicology in Serbia

Marija Kovač, The Piano as the Alter-Ego of Vasilije Mokranjac

Gorica Pilopović, Dušan Radić and the Socialist Realism

Max Stern, The Concept of Time in Compositions involving Indeterminacy and Improvisation

Carole Gubernikoff, John Cage: Sonatas and Interludes for Prepared Piano; Music of Changes

\section{No. 4-5, II/1994, I/1995}

Mirjana Vukićević Zakić, Bourdon in the Music Tradition of Zaplanje Arnold Berleant, Musical Generation

Evangelos Moutsopoulos, Alternative Processes in Artistic Creation

\section{No. 6, II/1995}

Dragoslav Dević, Béla Bartók and Yugoslav Folk Music

Nice Fracile, On Béla Bartók’s Track II: Béla Bartók’s Contribution to the Study of Rumanian Musical Tradition

Alois Mauerhofer, Spurensuche zur Rezeption von Bartoks Forschungen in der Deutschsprachigenvolkmusikforschung 
No. 7, I/1996

Anniversaries

Mirjana Živković, Striving for a Higher Artistic Order

Pavle Stefanović, The Drama of Josip Slavenski's Artistic Work

No. 8, II/1996

Dimitrije Golemović, Serbian Two-Part Singing I (Forms - Origin - Development)

Dragana Stojanović Novičić, Mihailo Vukdragović: The Artistic Path and Vocal Lyrics as pars pro toto

\section{No. 9, I/1997}

Dimitrije O. Golemović, Serbian Two-Part Singing, part II

Galliano Ciliberti, Per una nuova esegesi di Paul Hindemith

\section{No. 10, II/1997}

Marija Masnikosa, Vlastimir Peričić's Musicological Opus

Tatjana Marković, Poetica comico: Choral Works by Konstantin Babić

No. 11, I/1998

Andrijana Gojković, Focal Points of Gypsy (Romany) Music

\section{No. 12, II/1998}

Sanja Radinović, The Problem of Applicability of 'The Finnish Method' in the Melopoetic Analysis of Serbian Folk Songs

\section{No. 13, I/1999}

Miloš Krstić, Identifying Modern Jazz

Petar Janjatović, A Retrospect: Yugoslav Pop and Rock

Kler Levi, Youth and Popular Music in Bulgaria: Local vs. Global

\section{No. $15, \mathbf{I} / 2000$}

Dejan Despić, Marko Tajčević: The Master of Choral Sound and Harmony Bojana Cvejić, From a Work to the Author. Dimitrije Bivolarević Heccoe: String Quartet No. 2

\section{No. 16, II/2000}

Topic of the issue: Spiritual Music of the Balkan Region on the Occasion of 2000 Years of Christianity

Miloš Velimirović (USA), Sacred Music in the Balkans

Jane Kodžabašija (Macedonia), The Aspects of Reciprocal Influences and the Development of Church Chant of some Orthodox Nations in the Balkans in the 19th and 20th centuries 
Franz Metz (Germany), Das Banat und die Geistliche Musik Südesteuropas: Probleme un Ansätze einer Musikhistorischen Forschung

Vladeta Jerotić, The Psychological Effect of the Christian Liturgy

Ivana Perković, On the Eschatological Aspect of Serbian Church Chanting

Roksanda Pejović, Texts on Serbian Church Music in Serbian Journalism

Miloje Nikolić, Sacred Concert

Bogdan Đaković, Contribution to the History of Serbian Spiritual Choral Music - The Relations between Religious Service Tradition and Concert Practice

Constantin Catrina (Romania), Die Musik Byzantinischer Tradition in Rumänien und die Chrysantische Reform im Jahre 1814

Efstathios Makris (Greece), The Significance of Pitch in the 'New Method' of Greek

Church Music

Bojan Ortakov (Macedonia), The Aesthetics of Ohrid as the Basis of the Macedonian Musical Aesthetical Experience throughout Centuries

Anastasia Siopsi (Greece), Aspects of Ideology: Analyzing the Influence of Greek

Spiritual Tradition on the 'Modern Greek National Music'

Anastasia Georgaki (Greece), Spirituality in Electroacoustic Works Apokalypsis, Tetelestai and Kratima of the Greek Composer Michael Adamis

\section{No. 17, I/2001}

Roksanda Pejović, The Reflections of Fin-de-Siècle on Serbian Music

Dimitrije Golemović, Romani as an Important Factor in the Development of Serbian

Ritual Practice

\section{No. 18, II/2001}

Roksanda Pejović, Josif Marinković (1851-1931): Critical and Musicological Views Dragana Stojanović Novičić, To Observe the Others, to Discover Oneself: Mihailo Vukdragović's Music Reviews

\section{No. 19, I/2002}

Dragoslav Dević, Dinaric and Šop Singing in Serbia and Migrations

Dimitrije O. Golemović, Traditional Folk Song as a Symbol of a New Cultural Identity (based on the practice of Yugoslav refugees)

\section{No. 20, II/2002}

Pierre-Albert Castanet, Pour une musicologie du phenomene «techno»

Nico Schüler, Music Analysis of the Next Generation? Recent Developments in Computer-Assisted Music Analysis

Roksanda Pejović, The Centenary of Mihovil Logar's Birth (1902-1998): The Works of Mihovil Logar in the Context of Serbian Music Contemporary to Them 
Mikić, V.: From Studies to Thematic Issues - Symptoms ... (99-113)

No. 21, I/2003

Vesna Mikić, Music and/or Virtual Reality?

Colin Roche, Du sense politique dans l'utilisation des sons électroniques: Machinations de George Aperghis, TombeauX de Pierre-Albert Castanet et Le Grand Jeu de Bruno Mantovani

Marcel Cobussen, Deconstruction in Music: The Jacques Derrida - Gerd Zacher Encounter

No. 22, II/2003

Mladen Marković, Miodrag Vasiljević: The First Hundred Years

No. 23, I/2004

Katarina Marković-Stokes, The Evolution of the Durchbruch Idea: Adorno, Mahler, Beethoven and the $19^{\text {th }}$ Century Critical Tradition

No. 24, II/2004

Mirjana Veselinović-Hofman, Multimedia Archives as a Step Towards World Music Miško Šuvaković, Surplus Value: Musicology and Ethnomusicology in the Field of Discourse on World Music

No. 25, I/2005

Roksanda Pejović, Scenes with Musical Instruments in Byzantine and Post-Byzantine Art

Loren Y. Kajikawa, An Escape from the Planet of the Apes: Accounting for Cornelius's International Reception

\section{No. 26, II/2005}

\section{Core Issue: Acousmatics}

Andy Hamilton, The Concept of The Acousmatic

Nico Schüler, 'Acousmatic' and Beyond: On Otto Laske's Research on Musical Processes

\section{Studies}

Ana Stefanović, Vocal Lyricism of Dejan Despić

Tatjana Marković, Roksanda Pejović - Spiritus movens of Serbian Music Historiography

No. 27, I/2006

Branka Radović, Dejan Despić: Pesmarica (1950-2004) 


\section{No. 28, II/2006}

\section{Core Issue: Choral Production of Southeast Europe - to Stevan Mokranjac}

Dragoslav Dević, Stevan Stojanović Mokranjac - Collector of Folk Songs and Ethnomusicologist, 15-32

Roksanda Pejović, Choirs in Belgrade Music Life in the First Years After World War II (1944-1950), 33-47

Darja Koter, The Slovenian Singing Society - A Symbol of National and Cultural Identity 48-59

Refik Hodžić, The Rise of Choral Singing Organizations in the Area of Bosanska Krajina (1878-1941), 60-69

Miradet Zulić, Serbian Choral Societies in Tuzla and Bijeljina until 1914, 70-74

Milto Vako, The Origin and Development of Albanian Choral Music, 75-78

Petar Krumov, Bulgarian Choirs over the Past 50 Years, 79-86

Jernej Weiss, Contemporary Choral Production in Slovenia, 87-102

Gábor Baross, The Non-Professional Art of Choral Singing in Hungary , 103-114

Tatjana Marković, The Specific Nature of the Activities of Choral Societies in a MultiEthnic Context: A Case Study of Serbian Choral Societies in Banat (Pančevo and Veliki Bečkerek) in the $19^{\text {th }}$ century, 115-129

Balázs Mikusi, An 'Invented Tradition' for an 'Imagined Community': Male Choral Singing in Nineteenth-Century Germany, 130-144

Ivana Perković Radak, Rhetorical Strategies of Serbian Choral Church Polyphony Before 1914: Towards Genre Distinctiveness, 145-157

\section{No. 29, I/2007}

Sonja Cvetković, Composer, Journalist and Pedagogue Dragutin Čolić (1907-1987): On the Occasion of the Centenary of his Birth

\section{No. 30, II/2007}

\section{Core Issue: Studies, Interpretations, Views, Research and Tradition - Ballad}

Tijana Popović Mlađenović, The Story of the Ballad in Music

Sanja Radinović, Serbian Folk Ballads and Ethnomusicology: A Mission Impossible

Marjetka Golež Kaučič, The Slovenian Folk Ballad: A Genre Enigma

Anne Caufriez, Portuguese Ballad, its Specificities and Offshoots in the Mediterranean Chris Walton, Othmar Schoeck's Choral Ballad Der Postillon, and How Not to Write an Opera, 76-82

Jim Samson, Exploring Chopin's 'Polish Ballade', 83-94

Vesna Mikić, The First and the Last - Zdravko Čolić - the 'Guru' of Pop Ballad, 95-101

Miloš Krstić, Jazz Standards of a Ballad Character, 102-108

No. 31, I/2008 - in Serbian only 


\section{No, 32, II/2008}

\section{Core Issue: Improvisation}

Marcel Cobussen, Improvisation: An Annotated Inventory, 5-15

Tijana Popović Mlađenović, Improvisation as a Call for Communication 16-24

Vesna Peno, Two Aspects of Utilization of Improvisation in the Orthodox Church Chanting Tradition, 25-34

Daleen Kruger, Organ Improvisation in German Fundamenta of the 15th Century, 35-52

Hans Fidom, Organ Improvisation - An Introduction, 53-67

Wim van der Meer, Improvisation versus Reproduction, India and the World, 68-78

Kailan Rubinoff, (Re)Creating the Past: Baroque Improvisation in the Early Music Revival, 79-93

Jeff Warren, Improvising Music / Improvising Relationships: Musical Improvisation and Inter-relational Ethics, 94-106

Henrik Frisk, Improvisation, Computers, and Primary Process: Why Improvise with Computers?, 107- 118

David Toop, Search and Reflect: The Changing Practice of Improvisation, 119-129

Tanya Kalmanovitch, Contemporary Improvisation for Classical Musicians , 130-142

Dragana Jeremić Molnar \& Aleksandar Molnar, Surpassing Improvisation? Stockhausen's Concept of Intuitive Music, 143-156

Mirjana Veselinović-Hofman, Silence as Improvisation, 157- 161

Sara Ramshaw, Time out of Time: Derrida, Cixous, Improvisation, 162-175

Geraldine Finn, One Time Alone: Improvisation Takes Place, 176-199

\section{No. 33, I/2009}

Marija Masnikosa, The Life and Work of Ljubica Marić - 'Multifariousness of One, $12-35$

Jelena Novak, Undoing the Real of Music in works by Jasna Veličković , 36-46

\section{No. 34, II/2009}

\section{Core Issue: Music and Futurism}

Marjorie Perloff, 'The First Futurist Manifesto' Revisited, 7-15

John Heymans, From Helmholtz's Sensations of Tone to Russolo's Art of Noise, 16-36

Gergely Kertész \& Ádám Ignácz, Russolo and his Technical Utopia, 37-49

Dragana Stojanović Novičić, Work of Edgard Varèse and 'Futurist Music': Affinities (and Differences), 50-61

Diane L. Glazer, Among Friends: Italian Futurism Comes to America, 62-75

Vesna Mikić, Zenitism: A Possible View on the Avant-Garde Retreats of the Solitary Modernist Poetics of Josip Slavenski, 76-86 


\section{No. 35, I/2010}

Sonja Marinković, Work and Creation of Vučković and Rajičić: Facing the Challenges of Social Art, 17-27

Sanja Radinović, Suggestions for Transcribing Exotic Melodies: A cornerstone in the Babel Tower of Ethnomusicological Methodology , 28-28

Mirjana Veselinović-Hofman, Musical Notation: The More or the Less than Sound, 39-56

\section{No. 36, II/2010}

\section{Core Issue: Music \& Scene Today - Media Metamorphosis}

Dragana Jeremić Molnar, Lied: From Hausmusik to Film. On the Example of Franz Schubert's Winterreise, 13-28

Mirjana Veselinović-Hofman, Drama with Music Die Glückliche Hand by Arnold Schönberg as a Multimedia Project, 29-43

Ana Kotevska, Concert Metamorphoses of In/Visible and In/Audible, 44-53

Miško Šuvaković, Demateralization of the Stage: Epistemology of New Media in Perfomance Arts and Music, 54-62

Falk Hübner, Entering the Stage - Musicians as Performers in Contemporary Music Theatre, 63-74

Anastasia Siopsi, Music and the Scene in Stage Productions of Ancient Dramas and Comedies in Greece in the Last Decades of the Twentieth Century, 75-90

Anna Gadzinski, Appropriated Music: An Altered System of Relationships Between Music and Image, 91-100

Jelena Novak, Monsterization of Singing: Politics of Vocal Existence, 101-119

Ana Hofman, Socialist Stage: Politics of Place in Musical Performace, 120-134

\section{No. 37, I/2011}

Alexandros Charkiolakis, The War Requiems by Benjamin, Britten and Dmitri Kabalevsky: A Story of Differences, 15-23

Mirjana Veselinović-Hofman, Air, Ground, and Water of a Capital of Silence: Ivana

Stefanović's Radiophonic Epic Poem Metropola tišine / Stari Ras [Metropolis of Silence / Old Ras], 24-34

Bogumila Mika, Avant-Garde Discussions in the Late 1960s and Early 1970s, 35-46

\section{No. 38, II/2011}

\section{Core Issue: Contemporary Music At the Fringe}

Iva Nenić, Inner/Outer Borderland: Contemporary 'Reworking' of Gusle , 17-28 Mirjana Veselinović-Hofman, Music at the Periphery Under Conditions of Degraded Hierarchy between the Centre and the Margins in the Space of the Internet, 29-39 Virginia Anderson, John White and the Alternative British Experimental Aesthetic, 40-50 Sophie Stévance, Contemporary Music at the Fringe: The Example of 'Musique Actuelle' in Canada, 51-64 
Mikić, V.: From Studies to Thematic Issues - Symptoms ... (99-113)

No. 39, I/2012

Andrija Filipović, Noise and Noise: The Micropolitics of Sound in Everyday Life, 15-29

Valentina Radoman, On Comparative Research in Musicology: Peripheral vs. Central European Musical Culture and the Musicological Comparative Approach in the 20th Century, 30-48

Mirjana Veselinović-Hofman, The Nature of Post-modern Classicality in European Music, 49-57

Mirjana Zakić and Danka Lajić Mihajlović, (Re)Creating the (Folk Music) Tradition: The National Competition of Brass Orchestras at the Dragačevo Trumpet Festival, $58-79$

\section{New Sound's Thematic Series - Music on the Eve of the Third Millennium}

No. 9, I/1997

Mirjana Veselinović-Hofman, Serbian Music and 'Frozen' History: Initiating the Thematic Series Music on the Eve of the Third Millennium

No. 10, II/1997

Ulrich Dibelius, Komponieren gegen den Dogmenzwang

Tatjana Petrović, Communication as an Imperative of Creation

No. 11, I/1998

Linas Paulauskis, Modern Lithuanian Music: An Attempted Survey

No. 12, II/1998

Arnold Berleant, Some Observations on American Music Today

Marie-Thérèse Lefebvre, La contribution des femmes: À l'histoire de la musique au

Quebec

Tatjana Petrović, Communication as the Imperative of Creation

No. 14, II/1999

Pierre-Albert Castanet, Une approche française de la musique micro-tonale

No. $15, \mathbf{I} / \mathbf{2 0 0 0}$

Marcel Cobussen, The Dutch Ensemble Culture: Its Heterogeneity, Commitment and Social Embeddedness

No. 17, I/2001

Eduardo Miranda, Composers and Computer Music Technology in Brazil

No. 18, II/2001

Светлана Савенко, Авангарда и советская музыка 